\title{
Expectations of recovery and functional outcomes following thoracolumbar trauma: an evidence-based medicine process to determine what surgeons should be telling their patients
}

\author{
Rowan Schouten, FRACS, MBChB, ${ }^{1}$ Peter Lewkonia, MD, MSc, FRCSC, ${ }^{2}$ \\ Vanessa K. Noonan, PT, PhD, ${ }^{3}$ Marcel F. Dvorak, MD, FRCSC, ${ }^{4}$ \\ and Charles G. Fisher, MD, MHSc, FRCSC 4 \\ 1Orthopaedic Department, Christchurch Hospital, Christchurch, New Zealand; 'Division of Orthopaedics, Department of Surgery, \\ University of Calgary, Alberta; ${ }^{3}$ Rick Hansen Institute, Vancouver; and ${ }^{4}$ Department of Orthopaedics, Division of Spine, \\ University of British Columbia, Vancouver, British Columbia, Canada
}

OBJECT The aim of this study was to define the expected functional and health-related quality of life outcomes following common thoracolumbar injuries on the basis of consensus expert opinion and the best available literature. Patient expectations are primarily determined by the information provided by health care professionals, and these expectations have been shown to influence outcome in various medical and surgical conditions. This paper presents Part 2 of a multiphase study designed to investigate the impact of patient expectations on outcomes following spinal injury. Part 1 demonstrated substantial variability in the information surgeons are communicating to patients. Defining the expected outcomes following thoracolumbar injury would allow further analysis of this relationship and enable surgeons to more accurately and consistently inform patients.

METHODS Expert opinion was assembled by distributing questionnaires comprising 4 cases representative of common thoracolumbar injuries to members of the Spine Trauma Study Group (STSG). The 4 cases included a thoracolumbar junction burst fracture treated nonoperatively or with posterior transpedicular instrumentation, a low lumbar (L-4) burst fracture treated nonoperatively, and a thoracolumbar junction flexion-distraction injury managed with posterior fusion. For each case, 5 questions about expected outcomes were posed. The questions related to the proportion of patients who are pain free, the proportion who have regained full range of motion, and the patients' recreational activity restrictions and personal care and social life limitations, all at 1 year following injury, as well as the timing of return to work and length of hospital stay. Responses were analyzed and combined with the results of a systematic literature review on the same injuries to define the expected outcomes.

RESULTS The literature review identified 38 appropriate studies that met the preset inclusion criteria. Published data were available for all injuries, but not all outcomes were available for each type of injury. The survey was completed by $31(57 \%)$ of 53 surgeons representing 24 trauma centers across North America (15), Europe (5), India (1), Mexico (1), Japan (1) and Israel (1). Consensus expert opinion supplemented the available literature and was used exclusively when published data were lacking.

For example, 1 year following cast or brace treatment of a thoracolumbar burst fracture, the expected outcomes include a $40 \%$ chance of being pain free, a $70 \%$ chance of regaining pre-injury range of motion, and an expected ability to participate in high-impact exercise and contact sport with no or minimal limitation. Consensus expert opinion predicts reemployment within 4-6 months. The length of inpatient stay averages 4-5 days.

CONCLUSIONS This synthesis of the best available literature and consensus opinion of surgeons with extensive clinical experience in spine trauma reflects the optimal methodology for determining functional prognosis after thoracolumbar trauma. By providing consistent, accurate information surgeons will help patients develop realistic expectations and potentially optimize outcomes.

http://thejns.org/doi/abs/10.3171/2014.9.SPINE13849

KEY WORDS patient expectations; thoracolumbar trauma; functional prognosis

ABBREVIATIONS GRADE = Grades of Recommendations Assessment, Development and Evaluation; $\mathrm{HRQOL}=$ health-related quality of life; MeSH $=$ Medical Subject Headings; ODI = Oswestry Disability Index; PCS = Physical Component Summary; RMDQ = Roland Morris Disability Questionnaire; ROM = range of motion; SF-36 = 36-Item Short Form Health Survey; STSG = Spine Trauma Study Group.

SUBMITTED September 30, 2013. ACCEPTED September 25, 2014.

INCLUDE WHEN CITING Published online November 14, 2014; DOI: 10.3171/2014.9.SPINE13849.

DISCLOSURE The Spine Trauma Study Group received funding from Medtronic. Dr. Fisher reports a consultant relationship with Medtronic and NuVasive. 
$\mathrm{P}$ ATIENTS, their families, and society as a whole look to surgeons and other health care professionals for information on the predicted functional outcomes following thoracolumbar injuries. Without guidance, such injuries can often be incorrectly considered life- and career-altering by the lay public due to the aura surrounding spinal column pathology. The predictions provided to the patient by the surgeon and caregivers fundamentally influence a patient's recovery expectation.

Studies have repeatedly shown that patient expectations can significantly influence outcome. A systematic review-titled "Does how you do depend on how you think you'll do?"-found that positive expectations were associated with better health outcomes in 15 of 16 studies covering various medical and surgical conditions. ${ }^{41}$ A connection between expectation and outcome has also been demonstrated during the treatment of lumbar spine disorders, including low-back pain, ${ }^{25,28,29}$ disc herniation, ${ }^{37,45}$ and stenosis. ${ }^{19}$ This relationship has been less frequently examined after musculoskeletal trauma. Although initial expectations have been shown to influence subsequent disability following hip fracture ${ }^{10}$ and soft tissue ${ }^{17}$ and whiplash injuries, ${ }^{27}$ the association has been lacking in other clearly defined musculoskeletal injuries (e.g., other fractures and dislocations). ${ }^{25}$

To investigate the potential relationship between patient expectations and outcomes in spinal trauma we have initiated a multiphase study. Part 1 demonstrated substantial variability in the prognostic information spine surgeons were communicating to patients with spine injuries. ${ }^{18}$

The purpose of this study (Part 2) was to define the expected functional outcomes following common thoracolumbar injuries. To achieve this, we performed a literature review and supplemented the resulting data with consensus opinion of surgeons with extensive clinical experience in spine trauma, thus gathering expert opinion. The same methodology has been used to determine expected outcomes following cervical spine trauma. ${ }^{33}$ This information will help surgeons shape appropriate patient expectations following thoracolumbar injuries. It will also facilitate further assessment of the relationship of patient expectations and functional outcomes following spinal trauma.

\section{Methods}

\section{Cases and Questionnaire}

A questionnaire was created comprising 4 cases representative of common thoracolumbar injuries. These are summarized in Table 1. The cases included burst fractures, with varied location, patient demographic characteristics, and treatment strategies, and a flexion-distraction injury. For each scenario, 5 questions about anticipated functional outcomes were posed. These varied between cases but included pain, range of motion (ROM), restrictions in recreational activities, social life and personal care (all 1 year post-injury), timing of return to work or sports, and length of hospital stay.

All patients were assumed to be neurologically intact with single-system injuries, without major medical comorbidities, with adequate health care coverage, and with normal family or social support. Each recovery was pre- sumed to have occurred without local or systemic complications. The cases were kept as "straightforward" or "clean" as possible to minimize variability and enhance generalizability.

\section{Expert Opinion}

Questionnaires were distributed to the members of the Spine Trauma Study Group (STSG), a group of academic neurosurgical and orthopedic spine surgeons from Level 1 trauma centers worldwide with a subspecialty interest and significant practice in thoracolumbar trauma. Surgeons were asked to have their answers reflect "what they currently tell patients or their family when presented with such questions." Means for numerical values and modes for categorical answers from the survey data were used to represent consensus expert opinion.

\section{Systematic Literature Review}

A systematic review was performed to identify literature pertaining to the 4 scenarios. MEDLINE and EMBASE electronic databases were searched using Medical Subject Headings (MeSH) and key words pertinent to each case (Table 2). Inclusion and exclusion criteria were applied to identify data specific to each case. The search was limited to 1980-October 2010. A total of 750 English language abstracts were reviewed by the primary or secondary author, and potentially appropriate manuscripts were read in full. References from these manuscripts were analyzed to identify other articles containing relevant information. Original studies evaluating patient-specific outcomes were included with review articles, and studies devoid of relevant functional outcomes omitted.

For each case, the overall quality of evidence was assigned one of 4 ratings according to the Grades of Recommendations Assessment, Development and Evaluation (GRADE) Working Group framework.

\section{Synthesis of Literature and Expert Opinion}

A systematic and hierarchical approach was used to synthesize the data extracted from the systematic review with consensus expert responses regarding the same injuries and outcomes to define the functional prognosis of common thoracolumbar injuries. When adequate answers to an outcome question were available in the literature, these results were used. Where available, high-level evidence was used in preference to low-level or very lowlevel evidence. When published data were lacking, expert opinion was used exclusively. When literature and expert opinion differed significantly, published data were used preferentially unless these differences conceivably resulted from methodological limitations. Final numbers were often rounded to the nearest $5 \%$ to aid clinical use.

\section{Results}

\section{Expert Opinion}

The survey was completed by $31(57 \%)$ of 53 surgeons representing 24 trauma centers across North America (15), Europe (5), India (1), Mexico (1), Japan (1), and Israel (1). Opinions around the expected time for return to work 
TABLE 1. Summary of the clinical scenarios and outcomes studied

\begin{tabular}{|c|c|c|c|}
\hline Injury & Patient Description & Treatment & Outcomes Analyzed \\
\hline L-1 burst fracture & 31-yr-old male heavy laborer & Cast or brace & $\begin{array}{l}\text { Pain-free status at } 1 \mathrm{yr} ; \text { ROM recovery at } 1 \mathrm{yr} \text {; exer- } \\
\text { cise/sports participation at } 1 \mathrm{yr} \text {; timing of RTW; LOS }\end{array}$ \\
\hline L-1 burst fracture & $\begin{array}{l}\text { 20-yr-old male college } \\
\text { football player }\end{array}$ & $\begin{array}{l}\text { Open short-segment posterior } \\
\text { pedicle screw instrumentation }\end{array}$ & $\begin{array}{l}\text { Pain-free status at } 1 \mathrm{yr} ; \mathrm{ROM} \text { recovery at } 1 \mathrm{yr} \text {; ability } \\
\text { to return to contact sports; timing of RTW; LOS }\end{array}$ \\
\hline L-2 flexion-distraction injury & 30-yr-old male accountant & $\begin{array}{l}\text { Posterior instrumented stabiliza- } \\
\quad \text { tion (L1-3) }\end{array}$ & $\begin{array}{l}\text { Pain-free status at } 1 \mathrm{yr} ; \text { ROM recovery at } 1 \mathrm{yr} \text {; exer- } \\
\text { cise/sports participation at } 1 \mathrm{yr} \text {; timing of RTW; LOS }\end{array}$ \\
\hline L-4 burst fracture & $\begin{array}{l}\text { 50-yr-old female home- } \\
\text { maker }\end{array}$ & $\begin{array}{l}\text { Treated nonsurgically }\left(5^{\circ}\right. \\
\text { kyphosis) }\end{array}$ & $\begin{array}{l}\text { Pain-free status at } 1 \mathrm{yr} \text {; ROM recovery at } 1 \mathrm{yr} \text {; per- } \\
\text { sonal care/social life profile at } 1 \mathrm{yr} \text {; activity profile } \\
\text { at } 1 \mathrm{yr} ; \text { LOS }\end{array}$ \\
\hline
\end{tabular}

LOS = length of hospital stay; ROM = range of motion; RTW = return to work.

following specific injuries and occupations are detailed in Table 3.

\section{Systematic Literature Review}

A total of 38 publications were deemed appropriate. Reasons why studies were omitted included a lack of functional outcome measures, failure to separate results for patients with and without neurological injury, and an inability to distinguish data for thoracolumbar or low lumbar injuries from a more general cohort. Studies were also restricted to those that employed the selected treatment modality. While an attempt was made to select literature with outcome data corresponding to the follow-up interval in the survey, the paucity of data for most scenarios precluded this approach. A variety of outcome measures were used including many nonvalidated subjective self-reported scales.

The majority of studies reporting on thoracolumbar burst fractures involved data that were prospectively collected (overall GRADE quality rating: low) In comparison, outcomes following flexion-distraction injuries and low lumbar fractures were of lower quality, comprising almost exclusively retrospectively collected data (overall GRADE quality rating: very low).

\section{Synthesis of Literature and Expert Opinion}

The systematic review identified data for all 4 injuries; however, $6(30 \%)$ of 20 of the outcomes under investigation were not addressed by any of the available published literature. These outcomes were related to regaining ROM and return to sport or work. Expert opinion was used exclusively to predict the expected results for these 6 outcomes. Length of hospital stay was frequently influenced by concomitant injuries ${ }^{14,16}$ and thus expert opinion was used preferentially to reflect the anticipated inpatient stay following isolated spinal injuries. The Appendix (Tables 1-4) details the data extracted from the selected studies and expert opinion consensus for each case. Commentary on the information available for each individual scenario is presented below.

\section{Thoracolumbar Junction Burst Fracture Managed Nonsurgically}

Nine publications fulfilled the predetermined inclusion criteria for this scenario (overall GRADE quality rat- ing: low). ${ }^{1,2,8,14,16,30,48,49,51}$ The mean duration of follow-up ranged from 12 to 113 months.

The literature noted pain-free status at final follow-up in $80(38 \%)$ of 208 amalgamated patients. ${ }^{1,2,14,16,30,49,51}$ The survey responders predicted a mean $61 \%$ (range 25\%$90 \%$ ) chance of a patient's being pain free 1 year post-injury. No studies assessed ROM recovery; the mean value for likelihood of regaining pre-injury ROM at 1 year after injury based on the experts' survey responses was $68 \%$ (range 25\%-90\%).

At final follow-up, published studies noted "little or no restriction" in recreational activities in $67 \%-77 \%{ }^{14,16}$ of patients, while reported Roland Morris Disability Questionnaire (RMDQ) ${ }^{44}$ and Oswestry Disability Index (ODI) ${ }^{21}$ scores reflect low levels of functional disability. ${ }^{8,30,51}$ SF36 Physical Component Summary (SF-36 PCS) scores of $45^{8}$ and $47.4^{30}$ were also recorded, both below population norms. The majority (68\%) of experts predicted that patients should be able to participate in high-impact exercise and contact sports 1 year post-injury; $39 \%$ expected no limitations, and 29\% "some limitations."

In the report of their prospective randomized controlled trial, Wood et al..$^{52}$ commented on the timing of re-employment, stating that $17(71 \%)$ of 24 of conservatively treated patients with thoracolumbar burst fractures returned to work within 6 months. Thirty-nine percent of experts expected re-employment within 2 to 4 months, and $45 \%$ predicted a return to work between 4 and 6 months.

The length of inpatient stay reported in the literature ranged from 3 to 11 days. . $, 2,8,48,49,51$ Forty-eight percent of experts anticipated a 2- to 3 -day inpatient stay, while $35 \%$ predicted a 4- to 5-day stay.

\section{Thoracolumbar Junction Burst Fracture Treated With Posterior Instrumented Stabilization}

Twelve studies (overall GRADE quality rating: low) detailed relevant outcomes following posterior short-segment transpedicular stabilization of neurologically intact thoracolumbar (T-10 to L2-3) burst fractures. The mean duration of follow-up ranged from 12 to 68 months. ${ }^{6,11,13}$, 20,26,31,34,35,46,48,50,51

Pain-free status at final follow-up was noted in 33 (45\%) of 73 patients pooled from 5 studies. ${ }^{13,20,31,34,35}$ The mean survey response predicted a 62\% (range 12\%-90\%) chance of being pain free 1 year post-injury. No literature 


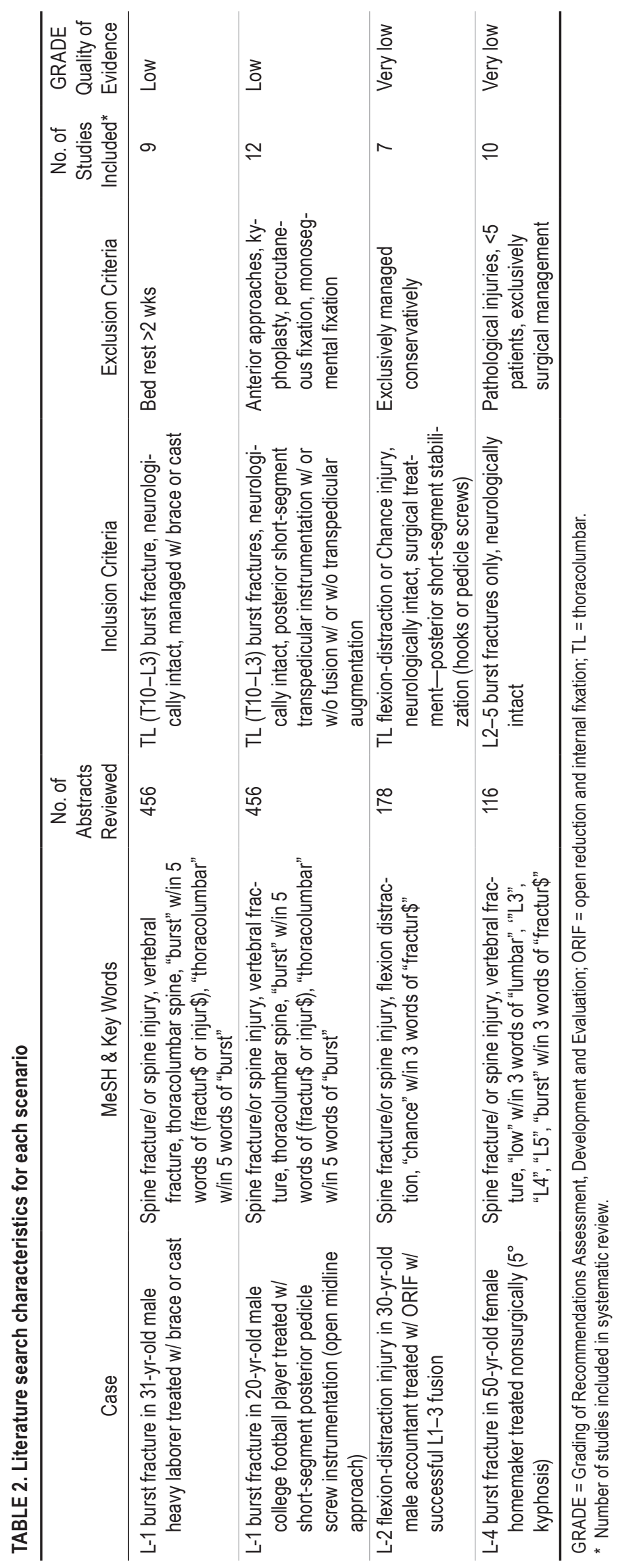


TABLE 3. Expert opinion for the anticipated time to return to work after a thoracolumbar junction burst fracture (in a manual laborer) and a thoracolumbar junction flexion-distraction injury (in an office worker)*

\begin{tabular}{ccc}
\hline $\begin{array}{c}\text { No. of } \\
\text { Mos }\end{array}$ & $\begin{array}{c}\text { L-1 Burst Fracture (treated } \\
\text { w/ brace or cast) in a Manual } \\
\text { Laborer }\end{array}$ & $\begin{array}{c}\text { L-2 Flexion-Distraction Injury } \\
\text { (treated w/ posterior short- } \\
\text { segment stabilization) in an } \\
\text { Office Worker }\end{array}$ \\
\hline$<1$ & $0 \%$ & $3 \%$ \\
\hline $1-2$ & $0 \%$ & $29 \%$ \\
\hline $2-4$ & $39 \%$ & $48 \%$ \\
\hline $4-6$ & $45 \%$ & $19 \%$ \\
\hline$>6$ & $16 \%$ & $0 \%$ \\
\hline
\end{tabular}

* Percentage values represent the proportion of experts favoring the specified time interval.

assessed post-treatment ROM, and expert opinion forecast a 57\% (range 0\%-90\%) chance that patients would regain their pre-injury ROM.

Sparse literature recorded the recreational activity profile of patients after short-segment instrumentation of neurologically intact thoracolumbar burst fractures; however, studies detailing health-related quality of life (HRQOL) outcomes often reported limitations, albeit minimal in the majority of cases. ${ }^{6,11,20,46,48,50,51}$ Experts most commonly (48\%) envisioned a return to "high impact exercises and contact sports with some limitations" 1 year after surgical treatment. Twenty-nine percent predicted a return to recreational activities "without limitations."

No published literature addressed return to contact $/ \mathrm{col}-$ lision sports after short-segment stabilization of a thoracolumbar level burst fracture. Over two-thirds of experts expected a return to high-level athletic pursuits (i.e., college football). Thirty-five percent anticipated this would take longer than 6 months, while 32\% forecast a return within 4-6 months. Thirty-two percent predicted this injury would end a college football career.

The average duration of hospital stay ranged from 8 to 12 days. ${ }^{26,34,35,46}$ The mode from the expert opinion survey predicted a 4- to 5-day inpatient stay (35\%).

\section{Thoracolumbar Junction Flexion-Distraction Injury Treated With Posterior Instrumented Stabilization}

Seven studies (overall GRADE quality rating: very low) reported relevant functional outcomes following flexiondistraction injuries at follow-up intervals ranging from 12 to 85 months. ${ }^{5,22,24,32,36,40,43}$ Four reported on the results obtained following contemporary posterior short-segment stabilization (pedicle screws or hooks). $22,36,40,43$

Two studies presenting pain outcomes in 27 neurologically intact patients following contemporary short-segment posterior stabilization noted that $48 \%$ reported no pain. ${ }^{36,43}$ The mean response of those surveyed predicted a $56 \%$ (range 10\%-90\%) chance of being free of back pain and stiffness 1 year post-injury.

No studies assessed post-injury ROM recovery, whereas experts estimated a mean $44 \%$ (range 0\%-90\%) chance of a patient regaining pre-injury spinal ROM post-injury.
Although exercise and sports participation were rarely specified, studies using a variety of scoring systems typically reported "full function" or "minimal disability" in more than $85 \%-90 \%$ of patients, while SF-36 PCS scores averaged below age- and sex-matched norms..$^{5,22,36,40,43}$ Of those experts surveyed, $32 \%$ proposed that patients would regain the ability to participate in low-impact exercise and sports without limitations, while $29 \%$ forecast that highimpact exercise and contact sports with some limitations would be possible.

None of the selected studies assessed the timing of reemployment, but all experts predicted a return to work within 6 months-29\% between $4-8$ weeks and $48 \%$ within 9-16 weeks.

An average inpatient stay of 5 days (range 3-10 days) was quoted for neurologically intact patients in one study. ${ }^{43}$ A 4- to 5-day admission was the most common prediction ( $42 \%$ overall) from the surgeons surveyed.

\section{Low Lumbar Burst Fracture Managed Nonsurgically}

Relevant patient-specific outcomes of neurologically intact, conservatively managed low (L2-5) lumbar burst fractures could be extracted from 10 retrospective case studies (overall GRADE quality rating: very low), with the average follow-up ranging from 29 to 79 months. ${ }^{3,4,7,9,12,15,23,30,39,47}$

Pooled data revealed that 27 (26\%) of 102 patients rated themselves as pain free or "completely recovered" at final follow-up. $3,4,7,9,12,15,23,39,47$ The mean survey response estimated a $59 \%$ (range 20\%-90\%) chance of being free of low-back pain 1 year after an injury that was treated nonsurgically.

No published literature assessed post-injury recovery of ROM. Expert opinion anticipated a 65\% (range 0\%90\%) chance of recovering pre-injury ROM.

The activity profile and personal care and social life limitations following low-lumbar fractures were inferred from articles that employed diverse outcome instruments. Studies recorded minimal limitations in recreational activity and a "return to previous activities" with "no" or "mild/ minor" limitations reported for $60 \%$ to $90 \%$ of neurologically intact patients. . $^{4,12,15,47}$ Others reported "no significant change in activities of daily living" or "full function" in all patients combined. ${ }^{3,9,39}$ In comparison, $97 \%$ of experts expected patients to regain the ability to manage all "personal cares" 1 year post-injury. Half of these experts expected no limitations, and half expected "few" limitations. Equally, 97\% of experts predicted "a normal social life" 1 year post-injury, with $58 \%$ anticipating "no limitations" and $32 \%$ expecting outdoor activity restrictions.

Protocols involving early protected mobilization resulted in a mean length of hospital stay ranging from 13 to 19 days. ${ }^{12,30,39}$ Alternatively, $61 \%$ of the surgeons surveyed anticipated a 2- to 3-day admission.

\section{Discussion}

The purpose of this study was to define the expected functional outcomes following common thoracolumbar injuries. This was accomplished by blending the best available evidence within the published literature with consensus expert opinion gleaned from a survey presented 
to spine trauma experts, i.e., members of the STSG. This study represents Part 2 of an investigation of the impact of patient expectation on outcomes following spinal trauma.

Different theories have been proposed to explain the association of expectations with outcomes. One recognized rationale suggests that "fulfilling expectations" is critical and advocates that minimizing the mismatch between what is expected and what is obtained is essential to optimizing satisfaction and global outcome.$^{38,42}$ Others suggest that high baseline expectations per se yield superior outcomes..$^{10,17,25,27}$ Regardless of which theory best represents the role of expectations in predicting treatment outcome, an accurate knowledge of expected outcomes is a necessary baseline to allow further investigation. To achieve a valid baseline, an evidence-based medicine methodology must be used.

From our comparisons, the only discernible disconnect between the literature and clinical expertise was in the proportion of patients expected to be pain free 12 months post-injury. For all injuries, published data reported fewer patients to be pain free compared with the mean percentage values for the opinion of the experts. This mismatch may represent an area where, due to unrealistic surgeon predictions, outcomes do not meet patients' expectations. It was also noted that the mean percentage values for expert opinion were remarkably similar for expectations regarding pain freedom regardless of injury, with predictions falling within a narrow range of $56 \%-62 \%$, despite wide individual variation.

Although the synthesis of best available literature and expert opinion reflects the optimal evidence-based medicine methodology for determining functional prognosis after thoracolumbar trauma, there are many limitations inherent to this study. These outcome predictions are limited by the quality and quantity of the research available. They also evolved from very specific case scenarios, with the specificity representing an effort to reduce variability and enhance generalizability. The validity of extrapolation to similar, but still different, cases encountered in clinical practice has not been established and will be guided by the clinician's expertise and experience. Issues concerning complications, neurology, and associated injuries could not be addressed in this study. In addition, many patients in the literature had premorbid conditions and concomitant injuries that may have negatively influenced their overall functional performance independent of their spinal pathology. While many studies quoted numbers of patients returning to work and sport, the retrospective nature of data collection often precluded information on the timing of these outcomes. Expert opinion was used almost exclusively for these domains. The follow-up interval in most published studies exceeded the 12-month time point investigated in this report. This variance in time to assessment may have introduced bias; nevertheless, experience suggests outcomes plateau after 1 year.

Only $57 \%$ of the members of the STSG completed the questionnaire. Although a group of experts tend to bias toward the null hypothesis, it is unknown whether the opinions of those that did not return the survey differed. The surgeons responding to the questionnaire, however, are experienced with thoracolumbar trauma and have established a strong research background in this area. The questionnaire was developed by the authors for the purpose of this study and therefore has not been validated. Although the STSG received funding from Medtronic, the content of this study limited any potential for this to bias the conclusions.

\section{Conclusions}

This synthesis of the best available literature and consensus opinion of surgeons with a subspecialty interest in spine trauma reflects the optimal methodology for determining functional prognosis and HRQOL outcomes after thoracolumbar trauma. By providing consistent, accurate information to patients, surgeons will help them develop realistic expectations and potentially optimize outcomes. This hypothesis will be the focus of further research.

\section{Acknowledgment}

We acknowledge the members of the STSG who assisted with the completion of the study questionnaire.

\section{References}

1. Ağuş H, Kayali C, Arslantaş M: Nonoperative treatment of burst-type thoracolumbar vertebra fractures: clinical and radiological results of 29 patients. Eur Spine J 14:536-540, 2005

2. Aligizakis A, Katonis P, Stergiopoulos K, Galanakis I, Karabekios S, Hadjipavlou A: Functional outcome of burst fractures of the thoracolumbar spine managed non-operatively, with early ambulation, evaluated using the load sharing classification. Acta Orthop Belg 68:279-287, 2002

3. An HS, Simpson JM, Ebraheim NA, Jackson WT, Moore J, O’Malley NP: Low lumbar burst fractures: comparison between conservative and surgical treatments. Orthopedics 15:367-373, 1992

4. An HS, Vaccaro A, Cotler JM, Lin S: Low lumbar burst fractures. Comparison among body cast, Harrington rod, Luque rod, and Steffee plate. Spine (Phila Pa 1976) 16 (8 Suppl):S440-S444, 1991

5. Anderson PA, Henley MB, Rivara FP, Maier RV: Flexion distraction and chance injuries to the thoracolumbar spine. J Orthop Trauma 5:153-160, 1991

6. Andress HJ, Braun H, Helmberger T, Schürmann M, Hertlein $\mathrm{H}$, Hartl WH: Long-term results after posterior fixation of thoraco-lumbar burst fractures. Injury 33:357-365, 2002

7. Andreychik DA, Alander DH, Senica KM, Stauffer ES: Burst fractures of the second through fifth lumbar vertebrae. Clinical and radiographic results. J Bone Joint Surg Am 78:1156-1166, 1996

8. Bailey CS, Dvorak MF, Thomas KC, Boyd MC, Paquett S, Kwon BK, et al: Comparison of thoracolumbosacral orthosis and no orthosis for the treatment of thoracolumbar burst fractures: interim analysis of a multicenter randomized clinical equivalence trial. Clinical article. J Neurosurg Spine 11:295-303, 2009

9. Blanco JF, De Pedro JA, Hernández PJ, Paniagua JC, Framiñán A: Conservative management of burst fractures of the fifth lumbar vertebra. J Spinal Disord Tech 18:229-231, 2005

10. Borkan JM, Quirk M: Expectations and outcomes after hip fracture among the elderly. Int J Aging Hum Dev 34:339350, 1992

11. Briem D, Lehmann W, Ruecker AH, Windolf J, Rueger JM, Linhart W: Factors influencing the quality of life after burst fractures of the thoracolumbar transition. Arch Orthop Trauma Surg 124:461-468, 2004 
12. Butler JS, Fitzpatrick P, Ni Mhaolain AM, Synnott K, O'Byrne JM: The management and functional outcome of isolated burst fractures of the fifth lumbar vertebra. Spine (Phila Pa 1976) 32:443-447, 2007

13. Butt MF, Farooq M, Mir B, Dhar AS, Hussain A, Mumtaz M: Management of unstable thoracolumbar spinal injuries by posterior short segment spinal fixation. Int Orthop 31:259264, 2007

14. Cantor JB, Lebwohl NH, Garvey T, Eismont FJ: Nonoperative management of stable thoracolumbar burst fractures with early ambulation and bracing. Spine (Phila Pa 1976) 18:971-976, 1993

15. Chan DP, Seng NK, Kaan KT: Nonoperative treatment in burst fractures of the lumbar spine (L2-L5) without neurologic deficits. Spine (Phila Pa 1976) 18:320-325, 1993

16. Chow GH, Nelson BJ, Gebhard JS, Brugman JL, Brown CW, Donaldson DH: Functional outcome of thoracolumbar burst fractures managed with hyperextension casting or bracing and early mobilization. Spine (Phila Pa 1976) 21:2170-2175, 1996

17. Cole DC, Mondloch MV, Hogg-Johnson S: Listening to injured workers: how recovery expectations predict outcomesa prospective study. CMAJ 166:749-754, 2002

18. Davidson D, Noonan VK, Dvorak MF, Zhang H, Fisher CG: The impact of patient expectations on outcome following treatment for spinal trauma. Part 1: What are spine surgeons telling their patients? Spine (Phila Pa 1976) 35:1807-1811, 2010

19. de Groot KI, Boeke S, Passchier J: Preoperative expectations of pain and recovery in relation to postoperative disappointment in patients undergoing lumbar surgery. Med Care 37:149-156, 1999

20. Defino HL, Canto FR: Low thoracic and lumbar burst fractures: radiographic and functional outcomes. Eur Spine J 16:1934-1943, 2007

21. Fairbank JC, Pynsent PB: The Oswestry Disability Index. Spine (Phila Pa 1976) 25:2940-2952, 2000

22. Finkelstein JA, Wai EK, Jackson SS, Ahn H, BrightonKnight M: Single-level fixation of flexion distraction injuries. J Spinal Disord Tech 16:236-242, 2003

23. Finn CA, Stauffer ES: Burst fracture of the fifth lumbar vertebra. J Bone Joint Surg Am 74:398-403, 1992

24. Gertzbein SD, Court-Brown CM: Rationale for the management of flexion-distraction injuries of the thoracolumbar spine based on a new classification. J Spinal Disord 2:176183, 1989

25. Gross DP, Battié MC: Recovery expectations predict recovery in workers with back pain but not other musculoskeletal conditions. J Spinal Disord Tech 23:451-456, 2010

26. Guven O, Kocaoglu B, Bezer M, Aydin N, Nalbantoglu U: The use of screw at the fracture level in the treatment of thoracolumbar burst fractures. J Spinal Disord Tech 22:417421, 2009

27. Holm LW, Carroll LJ, Cassidy JD, Skillgate E, Ahlbom A: Expectations for recovery important in the prognosis of whiplash injuries. PLoS Med 5:e105, 2008

28. Iles RA, Davidson M, Taylor NF: Psychosocial predictors of failure to return to work in non-chronic non-specific low back pain: a systematic review. Occup Environ Med 65:507-517, 2008

29. Kalauokalani D, Cherkin DC, Sherman KJ, Koepsell TD, Deyo RA: Lessons from a trial of acupuncture and massage for low back pain: patient expectations and treatment effects. Spine (Phila Pa 1976) 26:1418-1424, 2001

30. Koller H, Acosta F, Hempfing A, Rohrmüller D, Tauber M, Lederer S, et al: Long-term investigation of nonsurgical treatment for thoracolumbar and lumbar burst fractures: an outcome analysis in sight of spinopelvic balance. Eur Spine J 17:1073-1095, 2008
31. Lee Sh, Pandher D, Yoon K, Lee S, Oh KJ: The effect of postoperative immobilization on short-segment fixation without bone grafting for unstable fractures of thoracolumbar spine. Indian J Orthop 43:197-204, 2009

32. LeGay DA, Petrie DP, Alexander DI: Flexion-distraction injuries of the lumbar spine and associated abdominal trauma. J Trauma 30:436-444, 1990

33. Lewkonia P, Dipaola C, Schouten R, Noonan V, Dvorak M, Fisher C: An evidence-based medicine process to determine outcomes after cervical spine trauma: what surgeons should be telling their patients. Spine (Phila Pa 1976) 37:E1140E1147, 2012

34. Liao JC, Fan KF, Chen WJ, Chen LH: Posterior instrumentation with transpedicular calcium sulphate graft for thoracolumbar burst fracture. Int Orthop 33:1669-1675, 2009

35. Liao JC, Fan KF, Chen WJ, Chen LH, Kao HK: Transpedicular bone grafting following short-segment posterior instrumentation for acute thoracolumbar burst fracture. Orthopedics 32:493, 2009

36. Liu YJ, Chang MC, Wang ST, Yu WK, Liu CL, Chen TH: Flexion-distraction injury of the thoracolumbar spine. Injury 34:920-923, 2003

37. Lutz GK, Butzlaff ME, Atlas SJ, Keller RB, Singer DE, Deyo RA: The relation between expectations and outcomes in surgery for sciatica. J Gen Intern Med 14:740-744, 1999

38. Mannion AF, Junge A, Elfering A, Dvorak J, Porchet F, Grob D: Great expectations: really the novel predictor of outcome after spinal surgery? Spine (Phila Pa 1976) 34:1590-1599, 2009

39. Mick CA, Carl A, Sachs B, Hresko MT, Pfeifer BA: Burst fractures of the fifth lumbar vertebra. Spine (Phila Pa 1976) 18:1878-1884, 1993

40. Miyanji F, Fisher CG, Keynan O, Wing P, Boyd M, Dvorak MF: Flexion-distraction injuries of the thoracolumbar spine: health-related quality of life and radiographic outcomes. Top Spinal Cord Inj Rehabil 12:58-69, 2006

41. Mondloch MV, Cole DC, Frank JW: Does how you do depend on how you think you'll do? A systematic review of the evidence for a relation between patients' recovery expectations and health outcomes. CMAJ 165:174-179, 2001

42. Pager CK: Expectations and outcomes in cataract surgery: a prospective test of 2 models of satisfaction. Arch Ophthalmol 122:1788-1792, 2004

43. Ramieri A, Domenicucci M, Cellocco P, Raco A, Costanzo G: Effectiveness of posterior tension band fixation in the thoracolumbar seat-belt type injuries of the young population. Eur Spine J 18 (Suppl 1):89-94, 2009

44. Roland M, Morris R: A study of the natural history of back pain. Part I: development of a reliable and sensitive measure of disability in low-back pain. Spine (Phila Pa 1976) 8:141144,1983

45. Rönnberg K, Lind B, Zoëga B, Halldin K, Gellerstedt M, Brisby H: Patients' satisfaction with provided care/information and expectations on clinical outcome after lumbar disc herniation surgery. Spine (Phila Pa 1976) 32:256-261, 2007

46. Sanderson PL, Fraser RD, Hall DJ, Cain CM, Osti OL, Potter GR: Short segment fixation of thoracolumbar burst fractures without fusion. Eur Spine J 8:495-500, 1999

47. Seybold EA, Sweeney CA, Fredrickson BE, Warhold LG, Bernini PM: Functional outcome of low lumbar burst fractures. A multicenter review of operative and nonoperative treatment of L3-L5. Spine (Phila Pa 1976) 24:2154-2161, 1999

48. Shen WJ, Liu TJ, Shen YS: Nonoperative treatment versus posterior fixation for thoracolumbar junction burst fractures without neurologic deficit. Spine (Phila Pa 1976) 26:10381045,2001

49. Shen WJ, Shen YS: Nonsurgical treatment of three-column thoracolumbar junction burst fractures without neurologic deficit. Spine (Phila Pa 1976) 24:412-415, 1999 
50. Tezeren G, Kuru I: Posterior fixation of thoracolumbar burst fracture: short-segment pedicle fixation versus long-segment instrumentation. J Spinal Disord Tech 18:485-488, 2005

51. Wei FX, Liu SY, Liang CX, Li HM, Long HQ, Yu BS, et al: Transpedicular fixation in management of thoracolumbar burst fractures: monosegmental fixation versus short-segment instrumentation. Spine (Phila Pa 1976) 35:E714-E720, 2010

52. Wood K, Buttermann G, Mehbod A, Garvey T, Jhanjee R, Sechriest V: Operative compared with nonoperative treatment of a thoracolumbar burst fracture without neurological deficit. A prospective, randomized study. J Bone Joint Surg Am 85-A:773-781, 2003 (Erratum in J Bone Joint Surg Am 86-A:1283, 2004)

\section{Author Contributions}

Conception and design: Fisher. Acquisition of data: Schouten, Lewkonia. Analysis and interpretation of data: Fisher, Schouten.
Drafting the article: Fisher, Schouten, Lewkonia. Critically revising the article: Fisher, Schouten, Noonan, Dvorak. Reviewed submitted version of manuscript: Fisher, Schouten. Approved the final version of the manuscript on behalf of all authors: Fisher. Administrative/technical/material support: Fisher.

\section{Supplemental Information}

Previous Presentation

Portions of this paper were presented in 2011 at the Annual Canadian Spine Society Meeting (March 9-12, Quebec City, Quebec, Canada) and the New Zealand Orthopaedic Association Annual Meeting (October 9-14, Rotorua, New Zealand).

\section{Correspondence}

Charles G. Fisher, Blusson Spinal Cord Center, 6th Fl., 818 W. 10th Ave., Vancouver, BC V5Z 1M9, Canada. email: charles. fisher@vch.ca.

\section{Appendix}

Definitions were constructed from the combined results of data from the selected literature and consensus expert opinion for each of the 4 scenarios (Tables 1-4).

APPENDIX TABLE 1. An L-1 burst fracture ("stable pattern") in a 31-year-old heavy laborer, treated with cast or brace

\begin{tabular}{|c|c|c|}
\hline Question & Evidence & Guidelines \\
\hline \multirow{4}{*}{$\begin{array}{l}\text { What is the percent chance of being } \\
\text { free of low-back pain } 1 \text { year after } \\
\text { injury? }\end{array}$} & Literature & \multirow{4}{*}{$\sim 40 \%$} \\
\hline & $0 / 10$ on VAS pain scale: $8 / 23(35 \%)^{52}$ & \\
\hline & "no pain" (P1 on Denis Pain Scale): 72/185 (39\%)",2,14,16,30,49 & \\
\hline & $\begin{array}{l}\text { Survey } \\
\text { mean } 61 \% \text { (range } 25-90 \% \text { ) }\end{array}$ & \\
\hline \multirow{2}{*}{$\begin{array}{l}\text { What is the percent chance of patient } \\
\text { regaining pre-injury range of } \\
\text { motion? }\end{array}$} & $\begin{array}{l}\text { Literature } \\
\text { no published data }\end{array}$ & \multirow{2}{*}{$\sim 70 \%$} \\
\hline & $\begin{array}{l}\text { Survey } \\
\text { mean } 68 \% \text { (range 25-90\%) }\end{array}$ & \\
\hline \multirow{3}{*}{$\begin{array}{l}\text { Post-injury exercise and sports } \\
\text { participation? }\end{array}$} & $\begin{array}{l}\text { Literature } \\
\text { "active" lifestyle w/o restrictions: } 14(77 \%)^{16} \\
\text { "little or no restrictions" in recreational activities: } 16(67 \%)^{14} \\
\text { mean RMDQ scores } 2.4-3.9^{8,30,52}\end{array}$ & \multirow{3}{*}{$\begin{array}{l}\text { High-impact exercise \& contact sports } \\
\text { w/ no or minimal limitations }\end{array}$} \\
\hline & $\begin{array}{l}\text { mean ODI } 10.7^{52} \\
\text { mean LBOS } 50.2^{30} \\
\text { mean SF-36 PCS } 45,,^{8} 47.4^{3}\end{array}$ & \\
\hline & $\begin{array}{l}\text { Survey } \\
\text { high-impact exercise \& contact sports w/o limitation: } 12 \text { (39\%) } \\
\text { high-impact exercise \& contact sports w/ some limitations: } 9 \text { (29\%) }\end{array}$ & \\
\hline \multirow{2}{*}{$\begin{array}{l}\text { How long will it take to return to } \\
\text { work? }\end{array}$} & $\begin{array}{l}\text { Literature } \\
\text { w/in } 6 \text { mos: } 17 / 23(71 \%) \text {, further } 2 \text { btwn } 6 \& 24 \text { mos }^{52}\end{array}$ & \multirow{2}{*}{$\begin{array}{l}\text { Typically w/in 4-6 mos, although } 39 \% \\
\text { of experts expect } 2-4 \text { mos }\end{array}$} \\
\hline & $\begin{array}{l}\text { Survey } \\
\text { 4-6 mos: } 14(45 \%) \\
\text { 2-4 mos: } 12(39 \%)\end{array}$ & \\
\hline \multirow{4}{*}{ How long will patient be in hospital? } & $\begin{array}{l}\text { Literature } \\
\text { "isolated spine injuries": } 5.9 \text { days }^{16} \\
\text { patients meet discharge criteria at mean } 3 \text { days post-randomization }{ }^{8} \\
\text { average inpatient stay } 7.9-10.5 \text { davs } \text { s, } 2,14,16,48,49,52^{-19}\end{array}$ & \multirow{4}{*}{$3-5$ days $^{*}$} \\
\hline & average inpatient stay $1.9-10.5$ days $S^{1,2,1+1,1,0,7,+1,02}$ & \\
\hline & $2-3$ days: 15 (48\%) & \\
\hline & 4-5 days: $11(35 \%)$ & \\
\hline
\end{tabular}

LBOS = Low Back Outcome Scale; ODI = Oswestry Disability Index; RMDQ = Roland-Morris Disability Questionnaire (0 = no disability, 24 = maximum disability); SF-36 PCS = SF-36 Physical Component Summary; VAS = visual analog scale.

* For isolated spine injuries. 
APPENDIX TABLE 2. An L-1 burst fracture in a 20-year-old college football player, treated with short-segment pedicle instrumentation

\begin{tabular}{|c|c|c|}
\hline Question & Evidence & Guidelines \\
\hline \multirow{4}{*}{$\begin{array}{l}\text { What is the percent chance of being } \\
\text { free of low-back pain } 1 \text { year after } \\
\text { injury? }\end{array}$} & Literature & \multirow{4}{*}{$\sim 45 \%$} \\
\hline & "no pain" (Denis Pain Scale): 28/59 (47\%) $)^{13,31,34,35}$ & \\
\hline & SF-36 bodily pain scores 100: $5 / 14(36 \%)^{20}$ & \\
\hline & $\begin{array}{l}\text { Survey } \\
62 \% \text { (range } 12-90 \% \text { ) }\end{array}$ & \\
\hline \multirow{2}{*}{$\begin{array}{l}\text { What is the percent chance of } \\
\text { patient regaining pre-injury range } \\
\text { of motion? }\end{array}$} & $\begin{array}{l}\text { Literature } \\
\text { no published data }\end{array}$ & \multirow{2}{*}{$\sim 55 \%$} \\
\hline & $\begin{array}{l}\text { Survey } \\
57 \% \text { (range } 0-90)\end{array}$ & \\
\hline \multirow{3}{*}{$\begin{array}{l}\text { Post-injury exercise and sports } \\
\text { participation? }\end{array}$} & $\begin{array}{l}\text { Literature } \\
\text { "good" average LBOS }(n=80)^{48,50,51} \\
\text { "excellent" LBOS: } 12 / 24(50 \%)^{46} \\
\text { average activity score (range } 1-7): 4.92 \text { (pre-injury 5.42, } p<0.01)^{6}\end{array}$ & \multirow{3}{*}{$\begin{array}{l}\text { High-impact exercise \& contact sports w/ } \\
\text { limitations }\end{array}$} \\
\hline & $\begin{array}{l}\text { Hannover score: } 82 \text { (pre-injury } 98.5, p<0.01)^{6} \\
\text { mean SF-36 physical functioning index } 75^{20} \\
\text { mean SF-36 physical functioning index } 69 \text { (controls } 89)^{11}\end{array}$ & \\
\hline & $\begin{array}{l}\text { Survey } \\
\text { high-impact exercises \& contact sports w/ some limitation: } 15(48 \%) \\
\text { high-impact exercises \& contact sports w/o limitations: } 9(29 \%)\end{array}$ & \\
\hline \multirow[b]{3}{*}{$\begin{array}{l}\text { How long will it take to return to col- } \\
\text { lege football? }\end{array}$} & Literature & \multirow{3}{*}{$\begin{array}{l}2 / 3 \text { expect return to college football ( } 1 / 3 \\
\text { at less than } 6 \text { mos, } 1 / 3 \text { at more than } \\
6 \text { mos) } \\
1 / 3 \text { expect injury to be career ending }\end{array}$} \\
\hline & no published data & \\
\hline & $\begin{array}{l}\text { Survey } \\
\text { <26 wks: } 10(32 \%) \\
>26 \text { wks: } 11(35 \%) \\
\text { "never": } 10(32 \%)\end{array}$ & \\
\hline \multirow[b]{2}{*}{ How long will patient be in hospital? } & $\begin{array}{l}\text { Literature } \\
\text { mean } 8-12.4 \text { days (range } 1-35)^{26,34,35,46}\end{array}$ & \multirow[b]{2}{*}{$\sim 4-7$ days $^{*}$} \\
\hline & $\begin{array}{l}\text { Survey } \\
4-5 \text { days: } 11(35 \%) \\
2-3 \text { days: } 8(26 \%) \\
6-7 \text { days: } 8(26 \%)\end{array}$ & \\
\hline
\end{tabular}

* For isolated injuries. 
APPENDIX TABLE 3. An L-2 flexion-distraction injury in a 30-year-old accountant, treated with L1-3 posterior fusion (successful fusion)

\begin{tabular}{|c|c|c|}
\hline Question & Evidence & Guidelines \\
\hline \multirow{2}{*}{$\begin{array}{l}\text { What is the percent chance of being free } \\
\text { of low-back pain and stiffness } 1 \text { year } \\
\text { after injury? }\end{array}$} & $\begin{array}{l}\text { Literature } \\
\text { "no pain" (back pain rating): } 13 / 27(48 \%)^{36,43}\end{array}$ & \multirow{2}{*}{$\sim 50 \%$} \\
\hline & $\begin{array}{l}\text { Survey } \\
56 \% \text { (range 10-90) }\end{array}$ & \\
\hline \multirow{2}{*}{$\begin{array}{l}\text { What is the percent chance of patient } \\
\text { regaining pre-injury range of motion? }\end{array}$} & $\begin{array}{l}\text { Literature } \\
\text { no published data }\end{array}$ & \multirow{2}{*}{$\sim 45 \%$} \\
\hline & $\begin{array}{l}\text { Survey } \\
44 \% \text { (range } 0-90 \% \text { ) }\end{array}$ & \\
\hline \multirow[t]{2}{*}{ Exercise and sports participation? } & $\begin{array}{l}\text { Literature } \\
\text { work \& recreation "full function" (Back Pain Rating): } 34 / 35(97 \%)^{5,36,43} \\
\text { mean ODI score 11.5, } 15(88 \%) \text { "minimal disability"22 } \\
\text { mean SF-36 PCS } 39 \pm 11 \text {, mean NASS PDS } 38 \pm 11 \text { (both below age- \& sex- } \\
\quad \text { matched norms) }\end{array}$ & \multirow{2}{*}{$\begin{array}{l}\text { High-impact exercise \& } \\
\text { contact sports possible } \\
\text { w/ limitations }\end{array}$} \\
\hline & $\begin{array}{l}\text { Survey } \\
\text { low-impact exercises \& sports w/o limitations: } 10 \text { (32\%) } \\
\text { high-impact exercises \& contact sports w/ some limitations: } 9(29 \%) \\
\text { high-impact exercises \& contact sports w/o limitations: } 8(26 \%)\end{array}$ & \\
\hline \multirow[b]{2}{*}{ How long will it take to return to work? } & $\begin{array}{l}\text { Literature } \\
\text { no published data }\end{array}$ & \multirow{2}{*}{$\begin{array}{l}\text { Typically w/in } 2-4 \text { mos, } \\
\text { although } 29 \% \text { of experts } \\
\text { predict } 4-8 \text { wks }\end{array}$} \\
\hline & $\begin{array}{l}\text { Survey } \\
9 \text { to } 16 \text { wks: } 15(48 \%) \\
4 \text { to } 8 \text { wks: } 9(29 \%)\end{array}$ & \\
\hline \multirow{2}{*}{ How long will patient be in hospital? } & $\begin{array}{l}\text { Literature } \\
5.4 \text { days (range } 3-10)^{36}\end{array}$ & \multirow{2}{*}{$\sim 5$ days ${ }^{*}$} \\
\hline & $\begin{array}{l}\text { Survey } \\
4-5 \text { days: } 13(42 \%)\end{array}$ & \\
\hline
\end{tabular}

NASS PDS = National American Spine Society Lumbar Outcome Assessment Instrument pain/disability score.

${ }^{*}$ For isolated injuries. 
APPENDIX TABLE 4. An L-4 burst fracture in a 50-year-old homemaker, treated nonsurgically

\begin{tabular}{|c|c|c|}
\hline Question & Evidence & Guidelines \\
\hline \multirow{2}{*}{$\begin{array}{l}\text { What is the percent chance of } \\
\text { being free of low-back pain } 1 \\
\text { year after injury? }\end{array}$} & $\begin{array}{l}\text { Literature } \\
27 / 102(26 \%) \text { patients rated as "pain-free" or "completely recovered"3,4,7,9,12,15,23,39,47 }\end{array}$ & \multirow{2}{*}{$\sim 25 \%$} \\
\hline & $\begin{array}{l}\text { Survey } \\
59 \% \text { (range } 20-90 \% \text { ) }\end{array}$ & \\
\hline \multirow{2}{*}{$\begin{array}{l}\text { What is the percent chance of pa- } \\
\text { tient regaining pre-injury range } \\
\text { of motion in her back? }\end{array}$} & $\begin{array}{l}\text { Literature } \\
\text { no published data }\end{array}$ & \multirow{2}{*}{$\sim 65 \%$} \\
\hline & $\begin{array}{l}\text { Survey } \\
65 \% \text { (range } 0-90 \% \text { ) }\end{array}$ & \\
\hline \multirow[t]{2}{*}{$\begin{array}{l}\text { Personal care limitations/assis- } \\
\quad \text { tance } 1 \text { year post-injury? }\end{array}$} & $\begin{array}{l}\text { Literature } \\
\text { "no significant change in ADLs" (Denis Pain Scale): } 12 / 12(100 \%)^{4,9} \\
\text { "return to previous activities" (Smiley-Webster Scale): } 15 / 22(68 \%)^{3,47} \\
\text { activity returned to "pre-injury levels": } 18 / 20(90 \%)^{15} \\
\text { "full function": } 3 / 3(100 \%)^{39}\end{array}$ & \multirow{2}{*}{$\begin{array}{l}\text { Able to manage all ADLs } \\
\text { independently w/ few } \\
\text { limitations }\end{array}$} \\
\hline & $\begin{array}{l}\text { Survey } \\
\text { manage all personal cares w/o limitations: } 15(48 \%) \\
\text { manage all personal cares w/ few limitations: } 15(48 \%)\end{array}$ & \\
\hline \multirow[t]{2}{*}{$\begin{array}{l}\text { Social life/activity profile } 1 \text { year } \\
\text { post-injury? }\end{array}$} & $\begin{array}{l}\text { Literature } \\
\text { "return to previous activities" (Smiley-Webster Scale): } 15 / 22(68 \%)^{3,47} \\
\text { activity returned to "pre-injury levels": } 18 / 20(90 \%)^{15} \\
\text { "full function": } 3 / 3(100 \%)^{39} \\
\text { LBOS "excellent" or "good": } 3 / 5(60 \%)^{30} \\
\text { SF-36 PCS } 46.2 \pm 14.6^{30} \\
\text { RMDQ } 6 \pm 7.9^{30} \\
\text { returned to pre-injury level of recreational activity: } 6 / 10(60 \%)^{12} \\
\text { returned to pre-injury occupation \& recreational levels: "no limitations" } 13 / 28(46 \%) \text {, } \\
\text { "minor limitations" } 10 / 28(36 \%)^{7}\end{array}$ & \multirow[t]{2}{*}{$\begin{array}{l}\text { 2/3 expected to regain a } \\
\text { normal activity profile; } \\
\sim 1 / 3 \text { may experience limita- } \\
\text { tions } \mathrm{w} / \text { more energetic } \\
\text { activities }\end{array}$} \\
\hline & $\begin{array}{l}\text { Survey } \\
\text { normal social life w/o limitations: } 18(58 \%) \\
\text { normal social life w/ outdoor activity limitations (e.g., hikes): } 10(32 \%)\end{array}$ & \\
\hline \multirow{2}{*}{$\begin{array}{l}\text { How long will patient be in } \\
\text { hospital? }\end{array}$} & $\begin{array}{l}\text { Literature } \\
12.5-18.6 \text { days }^{12,30,39}\end{array}$ & \multirow[b]{2}{*}{$2-5$ days $^{*}$} \\
\hline & $\begin{array}{l}\text { Survey } \\
\text { 2-3 days: } 19(61 \%) \\
4-5 \text { days: } 9(29 \%)\end{array}$ & \\
\hline
\end{tabular}

ADLs = activities of daily living

* For isolated injuries. 